\title{
OSNOVNE DEMOGRAFSKE ODLIKE UGARSKE PREMA POPISU STANOVNIŠTVA IZ 1910. GODINE***
}

Predmet istraživanja bio je opšti popis stanovništva Ugarske iz 1910. g., a cilj da se na osnovu rezultata popisa prikažu osnovne demografske odlike stanovništva. Sem sadržajnosti popisa važna je činjenica, da se radi o najsavremenijem ugarskom popisu, koji je ujedno bio i poslednji pred njen raspad 1920. godine. Popis je simultano vršen u celoj Austrougarskoj. Autori su posebnu pažnju posvetili teritorijama današnje Vojvodine. Pri izradi studije korišćeni su prvenstveno sumarni i detaljni rezultati popisa za Ugarsku, podaci za austrijske krunovine, kao i relevantna stručna literatura. Pri obradi podataka upotrebljene su osnovne statističke metode, a u prezentaciji rezultata dijagrami, tabele i jedna karta. Popis oslikava Ugarsku u razvoju, uz rast stanovništva, sa dinamičnim migratornim kretanjima, sve izraženijim procesom urbanizacije, jačanjem građanskih elemenata društva i procesa industrijalizacije, rastom obrazovnog nivoa, određenim promenama u etničkoj strukturi i slično. Uz to, uočene su pojave koje su zabrinjavale savremenika: snažna ekonomska emigracija i rast broja porodica s jednim detetom - odnosno smanjenje nataliteta u odnosu na prethodna vremena. Popis iz 1910.g. je vanredno vredan istorijski izvor za izučavanje demografske, društvene i privredne istorije Vojvodine i Ugarske u doba dualizma (18671918).

Ključne reči: popisi, stanovništvo, 1910, Ugarska, Vojvodina, Austrougarska, demografija, migracije, statistika, konfesije.

\section{UVOD}

Razvijene države popise stanovništva vrše još od starog veka, s ciljem da utvrde realno stanje društva, njenu snagu kao i mogućnosti finansijskog i vojnog opterećenja. Uz brojne informacije o stanovništvu, podaci popisa predstavljaju dobru osnovu za detaljne analize složenih društvenih i privrednih procesa, koje mogu biti od

\footnotetext{
*gyz@ff.uns.ac.rs

Istraživanja na ovoj temi vršena su okviru rada na republičkom projektu broj 177002, pod naslovom Vojvođanski prostor u kontekstu evropske istorije, te se zahvaljujemo Ministarstvu za prosvetu, nauku i tehnološki razvoj za njenu velikodušnu finansijsku podršku.
} 
znatne koristi pri donošenju odluka u zakonodavstvu i državnoj upravi, kao i u vezi sa formiranjem dugoročne strategije razvoja raznih segmenata društva.

Prvi moderni opšti popis stanovništva u Austrijskoj monarhiji/Ugarskoj izvršen je u vezi sa državnim reformama kraljice Marije Terezije, koja je 1777. g. proklamovala uredbu o sveukupnom popisu stanovništva u statističke svrhe. Usled vladarkine skore smrti, planirani popis uspeo je sprovesti tek njen sin, car Josif II tokom 1784-1787. g. Sledeći korak u istoriji popisa stanovništva bila je odluka državnog sabora Ugarske kojom je potvrđena uredba cara Leopolda II iz 1790. o sprovođenju opšteg popisa. Međutim, zbog smrti Leopolda II i ratnih zbivanja u narednim godinama, planirana konskripcija nije sprovedena, ali su izvršeni parcijalni popisi 1805 , 1820. i 1838. godine. Za vreme mađarske revolucije 1848/49. pod upravom Eleka Fenješa formiran je prvi statistički ured Ugarske, ali je nestao sa porazom revolucije. U doba neoapsolutizma 1850. i 1857. bečka vlada je izvršila opšti popis.

Do istinskog razvoja statističke delatnosti i istraživanja na polju istorijske demografije u Ugarskoj došlo je posle austro-mađarske nagodbe 1867. g. Paralelno sa sprovođenjem odredaba Nagodbe i ustanovljavanjem mađarskih ministarstava, ustanovljen je Zemaljski statistički savet (Országos Statisztikai Tanács), koji je četiri godine kasnije transformisan u Zemaljski mađarski kraljevski statistički ured (Országos Magyar Királyi Statisztikai Hivatal). Po logici stvari, odmah po Nagodbi izvršen je prvi sveobuhvatni popis stanovništva (1869.) Ugarske. Drugi i treći popis (1880. i 1890.) već su rađeni uz primenu savremenih međunarodnih standarda, a u pripremi popisa iz 1890. učestvovala je i Mađarska akademija nauka. Daljem poboljšanju kvaliteta popisa (iz 1900. g.) doprinela je činjenica da je po zakonu iz 1897. Centralni statistički ured dobio znatan stepen samostalnosti, odnosno da su popisivači od 1900. honorisani za svoj rad i da su bili edukovani za taj posao (Faragó, 2008: 17-18, Bánszky, 2011).

Popis stanovništva iz 1910. godine bio je posebno motivisan zainteresovanošću stručnjaka, političara pa i javnosti, jer su se u prvim godinama 20. veka odigrali negativni događaji (zastoj u privrednom razvitku, unutrašnja i spoljnopolitička napetost, opadanje rate prirodnog prirasta, iseljavanje, sve prisutnija praksa rađanja samo jednog deteta u pojedinim oblastima Ugarske) čiji je utisak na stanovništvo valjalo sagledati.

Sprovođenje popisa odlučeno je VIII zakonskim člankom iz 1910. godine. Po njegovim odredbama popisivanje je trebalo sprovesti od prvog do desetog januara, pri čemu je namera bila da se utvrdi stanje u ponoć između 31. decembra 1910. i 1. 
januara 1911. godine. ${ }^{1}$ Posao organizacije, finansiranja i vršenja popisa utvrđen je detaljnim uputstvima. Uz stanovništvo popisani su stanovi i stambeni objekti. Popisivanje je, uz odgovarajući honorar, stavljeno u dužnost nastavnicima osnovnih škola koji su za vreme posla dobili status državnih službenika. Na osnovu ranijih iskustva pomno i detaljno je regulisan i unapređen rad kontrolora popisivača kao i način i forma predaje materijala Centralnom statističkom uredu. Naročito puno pažnje posvećeno je podacima $u$ vezi sa natalitetom, zanimanjem, obrazovanošću i migracijom stanovništva. Popisivano je tzv. prisutno stanovništvo, pri čemu se za svakog stanovnika ispunjavao jedan individualni listić (számlálólap, popisnica). Popisnica je bila detaljna, sa 29 pitanja i brojnim potpitanjima. Uz individualni listić popunjavani su posebni listići u kojima su beležene informacije o stambenim zgradama, njihovim odlikama, stanarima i načinu korišćenja. Prikupljeni podaci su proveravani, po potrebi je vršena revizija te je materijal slat na sređivanje, obradu i publikaciju u statističke urede u Budimpešti i Zagrebu. Finansijske troškove popisivanja snosile su opštine (samo popisivanje, prvu kontrolu podataka, prevoz i slične troškove), a troškove izrade popisnih formulara, detaljne obrade podataka i njihove publikacije pokrivala je država. Vrhovnim nadzorom sprovođenja popisa zaduženi su ministri finansija i trgovine, a u Hrvatskoj ban. Prema istim principima kao u Mađarskoj, popisivanje u Hrvatsko-slavonskoj kraljevini vršio je Zemaljski statistički ured, osnovan 1875. g. u Zagrebu (Buday, 1911: 463-478; Macura, 1953: 31-36).

Sem Ugarske, popis je sproveden u Austriji i u Bosni i Hercegovini. Interesantna karakteristična crta popisa jeste, da je on u BiH vršen posebno, s obzirom na činjenicu da usled različitih stavova Dvora i mađarskih političara u vezi sa mogućom pripadnošću oblasti, Bosna i Hercegovina nije priključena ni austrijskim ni ugarskim zemljama, već je njome rukovodilo zajedničko ministarstvo finansija.

Stanovništvo je u Ugarskoj o popisu, njegovim ciljevima i važnosti obaveštavano u svim gradovima i opštinama putem plakata, reklama u novinama i putem doboša. ${ }^{2}$ Radi ujednačenosti, tekst proglasa formulisao je Centralni statistički ured. Posebno korisnim se pokazalo objavljivanje informacije u božićnom broju

\footnotetext{
1 31. decembar bio je određen kao idealno vreme uzimanja podataka kod mađarskih popisa iz 1869., 1880., 1890., 1900., 1910.,1920. i 1930. godine (Rédei, 2006: 184).

${ }^{2}$ Praksa u Ugarskoj (prvenstveno u selima) da se informacije od javnog značaja (poput saopštenja organa civilne ili vojne vlasti, odluke pojedinih županija, ali i informacije od lokalnog značaja) obznane na taj način da za to zadužene osobe, obilazeći naselje kočijom ili peške, glasno pročitaju proglase, pri čemu su pažnju meštana privlačili udaranjem u bubanj, tj. u doboš.
} 
budimpeštanskih dnevnih novina koje su bile popularne u celoj zemlji (Lakatos, 2003: 173-174).

Naš cilj je bio da prikažemo najosnovnije rezultate popisa za teritoriju Ugarske i da skrenemo pažnju naučne javnosti na postojanje ovog bogatog istorijskog vrela. Praktično smo samo ,zagrebali““ površinu popisa, te postoji veoma široko polje za dalja istraživanja, kako u vezi sa današnjom vojvođanskom oblašću, tako i u smislu komparacije podataka sa ranijim ugarskim popisima stanovništva, sa paralelnim popisom iz austrijskog dela Monarhije, sa podacima popisa stanovništva Bosne i Hercegovine ili Kraljevine Srbije. Takođe bi bila poželjna dublja istraživanja pojedinih segmenata društvenog i privrednog života vojvođanskih oblasti. Pri izradi studije koristili smo pretežno sumarne i detaljne podatke popisa publikovane od strane Mađarskog statističkog ureda 1912. g., paralelne publikacije Carskokraljevskog statističkog ureda u Beču kao i relevantnu naučnu literaturu dostupnu pretežno na mađarskom jeziku.

Rezultati popisa objavljeni su u šest knjiga u periodu od 1912. do 1920. g., na 5.186 stranica gusto štampanih tabela i 16 geografskih karata. One su u celosti dostupne $\mathrm{u}$ elektronskoj formi na internet adresi Centralnog statističkog ureda $\mathrm{u}$ Budimpešti. ${ }^{3}$

\section{PROSTOR}

Podaci popisa za Ugarsku su tabelarno grupisani i obrađeni u skladu sa tadašnjim državnim i upravnim sistemom: po opštinama, u slučaju opština sa više od 20.000 stanovnika i po kvartovima, po municipalnim gradovima, ${ }^{4}$ županijama i

\footnotetext{
${ }^{3}$ Radi se o dragocenom sajtu za naše istraživače. Sem popisa iz 1910. g. tu se nalaze digitalizovani opšti popisi stanovništva Mađarske od 1784. do 1990. godine (15 popisa), mikrocenzovi 1963. do 1996. godine; serija podataka o etničkoj i religijskoj strukturi stanovništva 1880-1941. g., neki inostrani popisi, npr. popis stanovništva SSSR pred njen raspad, itd. Adresa Internet sajta je: Népszámlálási Digitális Adattár - Központi Statisztikai Hivatal Könyvtára, Magyarországi népszámlálások,mikrocenzusok, adatai internet hozzáféréssel

(https://library.hungaricana.hu/hu/collection/kozponti_statisztikai_hivatal_nepszamlalasi_di gitalis_adattar/).

${ }^{4} \mathrm{U}$ doba dualizma najvažniji i istaknuti organi državne organizacije Ugarske srednjeg nivoa bile su municipije (mađarski: törvényhatóság). Prema savremenoj političkoj teoriji njihova vlast nije poticala od kralja, odnosno od središnje vlasti, već je direktno izvirala iz mađarskog ustava. Kao takve, raspolagale su znatnom autonomijom koja se oslanjala na tri elementa: lokalna samoupravna prava (autonomija u vršenju njihovih unutrašnjih poslova, donošenje pravnih akata na istom nivou, sprovođenje tih akata, autonoman izbor činovnika,
} 
regijama Ugarske: Desna obala Dunava (Duna jobb partja), Leva obala Dunava (Duna bal partja), Međurečje Dunava i Tise (Duna-Tisza köze), Desna obala Tise (Tisza jobb partja), Leva obala Tise (Tisza bal partja), Ugao između Tise i Moriša (Tisza-Maros szöge), Preko prevoja Kiraljhago (Királyhágóntúl, praktično je teritorija Erdelja), Rijeka i njen okrug (Fiume és kerülete), Hrvatsko-slavonske države (Horvát-Szlavónországok). Potom su podaci popisa iz pomenutih regija sabirani posebno za Mađarsku, posebno za Hrvatsko-slavonsku kraljevinu, a na kraju je stajao zbir pomenuta dva entiteta. Radi lakšeg snalaženja u podacima popisa pomenute regije označili smo to na donjoj karti.

1. Karta. Regije Ugarske prema popisu iz 1910. godine.

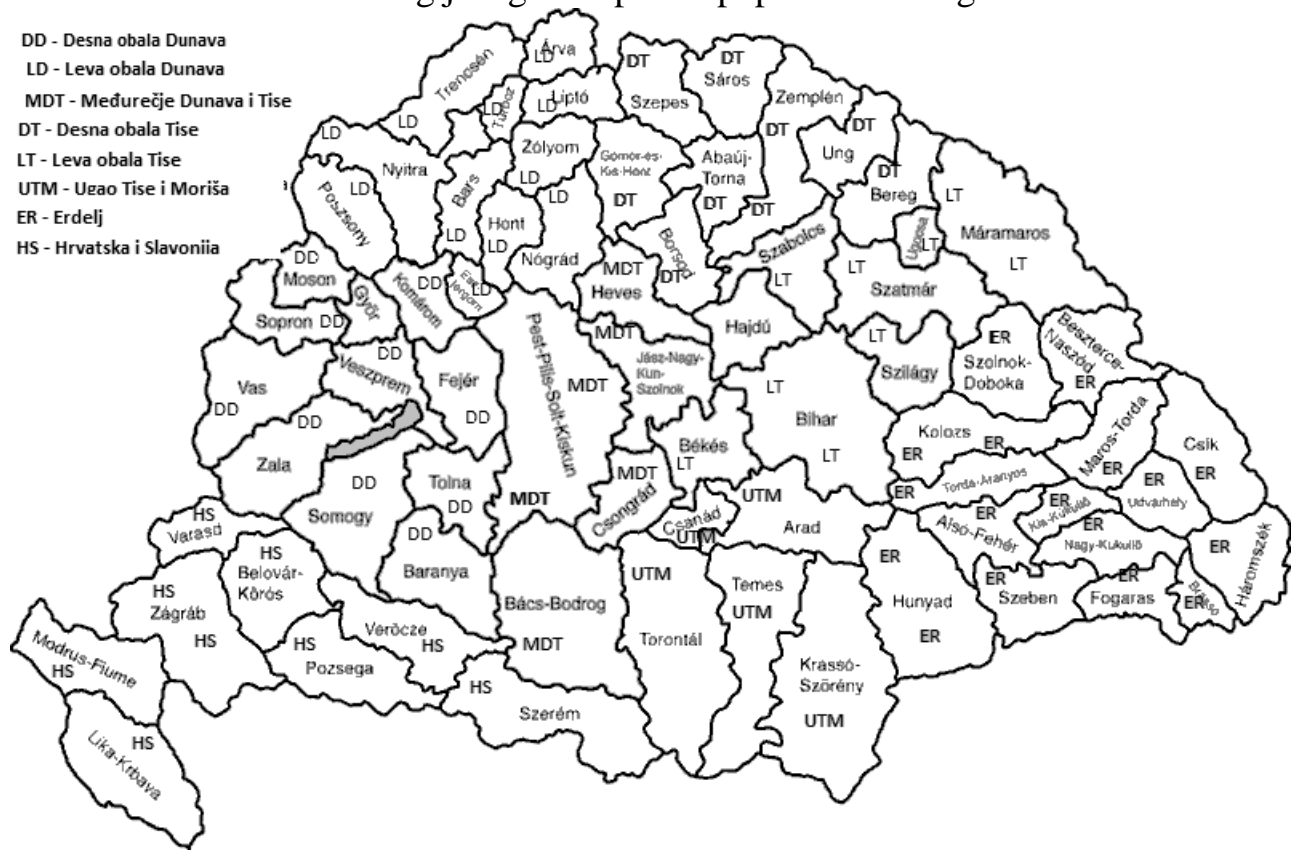

itd.); posredovanje u sprovođenju centralne državne vlasti i pravo da se bave pitanjima od opšteg zemaljskog značaja. Posle zakonske regulative 1870, 1876. i 1886. g. u Kraljevini Mađarskoj bilo je ukupno 89 municipija: 63 županija, 24 grada sa municipalnim pravom (mađarski: törvényhatósági joggal rendelkezö város), prestonica Budimpešta i slobodan grad Rijeka sa svojim okrugom. U Hrvatsko-slavonskoj kraljevini bilo je osam županija i četiri grada sa samoupravnim pravima (Zemun, Osijek, Varaždin i Zagreb). 
Prostor Ugarske 1910. godine iznosio je 325.411 kvadratnih kilometara, ${ }^{5}$ od čega je $42.541 \mathrm{~km}^{2}$ pripadalo Hrvatskoj i Slavoniji, a 282.870 kvadratnih kilometara Kraljevini Mađarskoj. Sa tim prostranstvom Ugarska je činila nešto više od polovine Dvojne monarhije bez BiH (Austrija je imala 300.005, a BiH $51.199 \mathrm{~km}^{2}$ ) i bila je na sedmom mestu po veličini u Evropi bez Rusije (Msk, 1912: 1*; Kks, 1912: 38*; Sdl, 1912: XXIII).

\section{BROJNO STANJE STANOVNIŠTVA.}

Brojno stanje stanovništva Ugarske ${ }^{6}$ bilo je 20.886 .487 žitelja, gotovo osam miliona manje od Austrije bez BiH. S tim stanovništvom Ugarska je bila peta zemlja na prostoru zapadne i srednje Evrope (Kks, 1912: 33*-35*). ${ }^{7}$ Uvećanje broja stanovnika u odnosu na stanje iz 1869. g. iznosilo je gotovo 7,7 miliona stanovnika (58\%), a u odnosu na 1900. godinu 1.631.928 duša. Primetan rast stanovništva bio je u skladu sa promenama koje su se u Ugarskoj javile od 1880. g., nakon poslednjih epidemija kolere (1866-67. i 1872-74): poboljšanje zdravstvenih i higijenskih uslova života, brže opadanje stope mortaliteta od stope nataliteta (Tóth, 2002: 26).

Rast stanovništva rezultiralo je i uvećanjem gustine stanovnika sa 59,2 na 64,2 žitelja po $\mathrm{km}^{2}$. Najgušće naseljena županija bila je Varaždinska, sa 120,3 žitelja po $\mathrm{km}^{2}$, a daleko ispod proseka, sa manje od 30 stanovnika, bile su županija Čik i Besterce-Nasod. Od županija na teritoriji današnje Vojvodine gustina stanovništva Sremske županije podudarala se sa zemaljskim prosekom županija (58,8 stanovnika po $\mathrm{km}^{2}$ ), Torontalska je bila za nijansu gušće naseljena, a Bačko-Bodroška iznad proseka $(71,6)$. Najgušće naseljeni grad Ugarske, kao što smo i očekivali, bila je Budimpešta sa 4.538 stanovnika na $\mathrm{km}^{2}$, a u našem regionu Temišvar sa 853,6 i

\footnotetext{
${ }^{5}$ Popis iz 1900-te godine konstatuje površinu od 324.851 kvadratnih kilometara. Razlika od 560 kvadratnih kilometara je rezultat delom ispravki na osnovu tačnijih proračuna, a manjim delom usled ispravki granica prema Rumuniji.

${ }^{6}$ Terminologija koju koristimo u ovoj studiji je u skladu sa onovremenom terminologijom i upravnom podelom: pojam Ugarske odnosi se na sve zemlje krune Svetog Stefana pod upravom mađarske i hrvatske vlade, tj. na Mađarsku, Erdelj, Hrvatsku i Slavoniju bez Dalmacije, nad kojom je administrirala bečka vlada. Pod Mađarskom se podrazumeva Mađarska, Erdelj i Rijeka, a hrvatsko-slavonske ili u mađarskoj tadašnjoj terminologiji tzv. pridružene zemlje, podrazumevaju hrvatske županije i gradove bez Dalmacije. Radi lakšeg snalaženja u ovom i ranijim popisima nazive naselja smo koristili u obliku u kojem se $\mathrm{u}$ popisima nalaze i koji su familijarni srpskim istraživačima.

${ }^{7}$ Demografi su utvrdili da je na oblastima koje je 1910. g. obuhvatala Ugarska, osamdeset godina kasnije živelo 31,6 miliona ljudi (Rédei, 2006: 71).
} 
Zemun sa 305,9 stanovnika po $\mathrm{km}^{2}$ (prosek municipija je bio 331,6) (Msk, 1912: 2*, $25 *-26 *)$.

Rast stanovništva bilo je jedno od pitanja koje je najviše zanimalo savremene demografe, a takođe i širu javnost - i predstavljao je složen i teško rešiv problem. Realan rast stanovništva zemlje u odnosu na 1900. godinu bio je $8,5 \%$, što je bilo primetno manje nego u prethodne dve decenije, kada je prelazio $10 \%$. Pomenuto usporavanje rasta međutim nije proisticalo iz smanjenja prirodnog prirasta stanovništva već iz sve većeg obima emigracije. Prirodan rast stanovništva je u Ugarskoj zapravo bio veći od prethodnih decenija (u Mađarskoj 11,8\% u hrvatskim oblastima čak 13,4\%), ali se broj iseljenih sa 166.746 u periodu od 1900. do 1910. godine gotovo učetvorostručio na 646.540 , te smanjenje realnog rasta stanovništva proističe iz te činjenice. Pomenimo, da je realna stopa rasta stanovništva u Ugarskoj bila osetno manja od one u Austriji, Nemačkoj, Velikoj Britaniji i Rusiji, ali je bila već od realnog rasta stanovništva u Italiji, Francuskoj ili Španiji (Msk, 1912: 25*-26*; Hanák, 1983: 403).

Kao što vidimo emigracija je udarila vidljiv pečat na realan rast stanovništva Ugarske i izazivala je brojne diskusije u ugarskoj javnosti. Podaci popisa iz 1910. rečito svedoče o emigraciji. Za deset godina broj stanovnika Ugarske koji su živeli u inostranstvu je više nego udvostručen: sa 240.220 iz 1900. godine ta brojka je povećana čak na upečatljivih 598.219. Podaci upućuju na konstataciju da su, srazmerno stanovništvu, migratorna kretanja 1900-1910. bila življa u hrvatskoslavonskim oblastima nego u Mađarskoj: beleži se i više stranaca (2,9\% prema $1,1 \%)$ i više emigranata $(5,7 \%$ prema $2,5 \%$ ), a činjenica takođe jeste da su iseljenici iz hrvatsko-slavonskih oblasti (bez Dalmacije i Rijeke sa okolinom) davali 22,5\% svih iseljenika (145.317 lica) iz Ugarske. Posmatrajući podatke po ugarskim municipijama najviše emigranata je bilo iz oblasti leve obale Tise i ugla između reke Moriš i Tise, gde je broj iseljenih u pojedinim naseljima čak udesetostručen. Popis dalje konstatuje okolnost, da je iz županija bilo više iseljenika nego iz gradova, a manje stranacaimigranata, dok je situacija u gradovima bila obrnuta. Ujedno, u odnosu na ranija vremena, u gradovima je uočeno smanjenje broja stranaca, što su savremenici komentarisali sa izvesnim zadovoljstvom, verujući da to ukazuje na jačanje finansijsko-industrijskog razvoja na osnovi domaćih snaga (Msk, 1912: $2 *-3 *){ }^{8}$

8 Prema procenama, u doba dualizma iselilo se iz Ugarske približno 1,8-2 miliona stanovnika u SAD i 300-400.000 u Nemačku, Austriju i Rumuniju. Prema podacima državne statistike 1899-1913. legalno se iz zemlje iselilo približno 1,4 miliona lica. Od iseljenika se vratilo njih oko pola miliona. Motivi iseljenja su bili želja za zaradom ili barem sigurnom egzistencijom; mnogi su planirali da u SAD steknu ušteđevinu od koje će vrativši 
U većini oblasti današnje Vojvodine bio je vidan gubitak stanovništva usled migracije: realan rast stanovništva Bačko-Bodroške i Torontalske županije iznosio je sukcesivno 12,9\% i 9,2\%, međutim realan rast od toga bio je znatno niži: 4,7\% i $0,7 \%$. Praktično, gubitak stanovništva te dve županije usled migracije, za deset godina, iznosio je gotovo sto hiljada stanovnika. U Sremskoj županiji gubitak je bio primetno niži: 9.192 , pri čemu je realan rast stanovništva bio $8,8 \%$, a prirodni rast 10,8\% (Msk, 1912: 25*-26*).

Najslabiji prirodni prirast stanovništva notiran u Ugarskoj je u uglu Tise i reke Moriš (8,2\%), koji je emigracija dalje prepolovila na svega 4,2-postotni realan rast. Stanovništvo dve županije: Ličko-Krbavske i Arve znatno je opalo usled velikog obima emigracije (Msk, 1912: 1*-2*). U apsolutnim brojevima u celoj Ugarskoj najviše migranata bilo je iz Torontalske (50.354), Bačko-Bodroške (49.031) i Zagrebačke županije (35.239). Međutim, i uz tolike gubitke Bačko-Bodroška (632.560) i Torontalska županija (594.343) bile su na drugom i trećem mestu po brojnosti stanovništva iza županije Pešt-Piliš-Kiškun (1.030.836), a Subotica sa svojih 94.610 žitelja bila je na trećem mestu među ugarskim gradovima, iza Budimpešte i Segedina.

Uz sve gubitke pretrpljene usled ekonomske emigracije, stanovništvo Ugarske je ipak i dalje sasvim solidno bilo u rastu, pri čemu je najveći stvarni prirast stanovništva beležen u međurečju Dunava i Tise i na levoj obali Tise (Msk, 1912: $\left.25^{*}-26^{*}\right)$. Na zemaljskom nivou stanovništvo gradova raslo je u većoj meri od stanovništva županija - međutim, ne usled većeg prirodnog rasta, već usled useljavanja iz županijskih oblasti. U gradovima sa municipalnim pravom (njih 31) stanovništvo se uvećalo za prosečnih $17,8 \%$, u županijama za više nego upola manje: za 7,4\%. ${ }^{9}$ Useljavanje žitelja iz sela u gradska naselja bio je markantan trend koji se može pratiti još od popisa iz 1880. godine. Ukoliko sem gradova u pravnom smislu, u gradove računamo i naselja iznad 10.000 stanovnika, koji su se brzo razvijali i imali sve više građanski karakter, možemo konstatovati da je u Mađarskoj, bez hrvatskih

se kući započeti svoj posao. Tri četvrtine iseljenika poticalo je iz seoskih oblasti i bili su siromašni seljaci, bereši, sluge, ostali su bili većinom industrijski radnici i nadničari. U pogledu etničkog sastava 33\% činili su Mađari, 25\% Slovaci, $18 \%$ Nemci, $15 \%$ Rumuni 4,5\% Rusini, i svega 2,6\% južnih Slovena, tj. više od dve trećine činili su pripadnici nemađarskih narodnosti. Iz vojvođanskih oblasti bilo je najviše emigranata iz Banata, zatim iz Bačke pa iz Srema. Relativno je bilo manje iseljenika iz gradova. Najviše su se iseljavali Nemci (Györe, 1992: 849-850, Hanák, 1983: 412-413).

${ }_{9}$ Proces kretanja stanovništva ka gradovima i gubitak stanovnika u županijama rečito ilustruje podatak, da su gradovi na zemaljskom nivou za deset godina imali rast od 208.734 žitelja, a županije su usled prekomorske emigracije i unutrašnje migracije izgubile 855.274 duša (Msk, 1912: 2*). 
oblasti, 23,7\% stanovnika živelo u gradskim naseljima. Prema statističkim podacima povećanje najvećeg mađarskog grada, Budimpešte, je usporeno: stvarni prirast je sa 44,8\% u periodu 1890-1900. opao na 20,2\% u narednoj deceniji. Dinamiku porasta stanovništva Budimpešte nadmašilo je čak devet gradova: (Marošvašarhelj sa 30,7\% Satmarnemeti sa 29,8\%, Zagreb sa $29,6 \%$, Rijeka sa $27,5 \%$, Nađavarad sa $27,9 \%$, Osijek sa 25,9\%, Koložvar sa (23,8\%), Debrecin 23,6\% i Temišvar sa realnim prirastom od 22,5\%). Ipak, treba da imamo na umu da je usled povećanih cena nekretnina u Budimpešti broj onih koji su se iselili u okolinu bio približan broju onih koji su se uselili u glavni grad Mađarske, kao i da je iseljavanje u pravcu jeftinijih nekretnina praktično značilo jačanje ili nastajanje naselja u okolini Budimpešte, koji su ubrzo prerasli u periferne delove samog grada, te je Budimpešta u ovo vreme sa svojim prigradskim naseljima zapravo imala približno 1,1 miliona stanovnika.

Uz pomenute gradove popisi svedoče o dinamičnom razvoju Miškolca, Đera, Pečuja i Košica - gradova koji su svoje tradicije slobodnih kraljevskih gradova, administrativnih i saobraćajnih središta uspeli spojiti sa procesom industrijalizacije. Uz njih izrastao je čitav niz gradova u novim industrijskim oblastima. Tempo razvoja starih gradova u Erdelju i Alfeldu bio je sporiji i u pogledu značajki moderne industrijalizacije manjkaviji (Hanák, 1983: 410).

Situacija u vojvođanskim gradovima bila je u skladu sa zemaljskim trendom: beleži se uvećanje broja stanovništva usled useljavanja - iako je i iz njih bilo emigranata, zbir je bio ipak pozitivan. Banatski municipalni gradovi Temišvar, Vršac i Pančevo beležili su natprosečan realan rast $(22,5 \%, 8,6 \%, 9,8 \%)$ usled migracije, pri čemu je najveći priliv išao u pravcu Temišvara, čak 12.630 lica. Kao posledica useljavanja u grad (1.685 lica), Zemun je beležio gotovo šestostruko viši realan rast $(13,6 \%)$ od prirodnog $(2,4 \%)$. Uz prirodan prirast, broj stanovnika Subotice i Novog Sada takođe je uvećan useljavanjem u grad (3.223 i 2.655 osoba). Za razliku od pomenutih gradova u Somboru je konstatovan negativan zbir emigranata i useljenika od 282 lica. Realan rast stanovnika u Subotici, Novom Sadu i Somboru iznosio je sukcesivno 13,9, 14,7 i 3,8 odsto. Primetimo, da je useljavanje u gradove bilo dobro došlo usled prilično niskog prirodnog priraštaja u njima (Msk, 1912: 25*-26*).

Ekonomska emigracija dobila je kod savremenika širok publicitet i ozbiljno je zabrinjavala javne delatnike, međutim činjenica jeste da je od nje karakterističnija bila unutrašnja migracija: popis iz 1910. beleži 5,5 miliona stanovnika koji su se u prethodnim decenijama preselili iz svog rodnog u neko drugo mesto - obično u gradska naselja u svojoj ili udaljenijoj županiji (od njih 2,2 miliona migriralo je tokom 1900-1910.). Ukoliko znamo da su ukupni gubici kroz emigraciju od 1869. g. premašili dva miliona, a broj imigranata se kretao između trista i četiristo hiljada, tek 
onda stičemo sliku o obimu migracija u Ugarskoj tokom perioda dualizma (Györe, 1992: 844, Hanák, 1983: 412-413).

Od ukupnog broja stanovnika 1910. njih 141.743 služilo je u vojsci AustroUgarske, što je za 9.524 više nego deset godina ranije. Pri tome, nesrazmerno veći broj vojnika poticao je iz slavonsko-hrvatskih oblasti, što se objašnjava činjenicom da je zbog ratne opasnosti iz 1909. g. više vojnika dignuto iz oblasti koje su bile direktno ugrožene (Msk, 1912: 1*).

Popis iz 1910. godine konstatuje 278.130 stranaca sa boravištem u Ugarskoj, što je bilo za $32.586(13,3 \%)$ više nego deset godina ranije. Ipak, to uvećanje bilo je znatno umerenije nego u prethodnom desetleću, kada je iznosio 58.000 duša. Na osnovu analize detaljnih podataka popisa se čini da je pravac useljavanja stranaca bio $\mathrm{u}$ vezi sa popunjavanjem praznina nastalih intenzivnim iseljavanjem iz određenih oblasti, te je u njima i bilo srazmerno najviše imigranata. Tako je uz Budimpeštu, koja je privlačila migrante brojnim radnim mestima i sjajem pravog evropskog velegrada, najviše useljenika bilo u pojedinim županijama u severnim regijama Ugarske, u koje su se useljavali pretežno rimokatolici ili unijati iz Galicije (Msk, 1912: 2*).

\section{Rodna i starosna struktura stanovništva}

U pogledu rodne strukture stanovništva popis je registrovao bitnu promenu dotadašnje tendencije: ranijih decenija broj muškaraca je sustizao broj žena, ali je od 1900. do 1910. taj balans izmenjen u korist žena - što se takođe objašnjava povećanim obimom prekomorske emigracije. Smanjivanje broja muškaraca u ukupnom stanovništvu bilo je s time više vredno pažnje, da je njihov broj u prirodnom priraštaju iz godine u godinu nadmašio broj ženske dece. Na vezu između većeg broja žena i emigracije ukazuje činjenica da je najveća nesrazmera notirana upravo u municipijama sa najvećim obimom emigracije (županije Arva, Lipto, Trenčen, Abauj-Torna, Šaroš, Ung, Zemplen, Modruš i Rijeka) u kojima je na 1.000 muškaraca dolazilo više od 1.100 žena. Slična je bila situacija na nivou hrvatsko-slavonskih oblasti: dok je ovde u proseku 1900-te godine bilo više muškaraca od žena - na 1.000 muškaraca dolazilo je 998 žena - dotle se do 1910. g. situacija korenito promenila i na 1.000 muškaraca dolazilo je 1.045 žena (Msk, 1912: $\left.3^{*}\right)$.

Popis je takođe uočio slučajeve koji su se razlikovali od opšte tendencije: bilo je dosta županija sa više muškaraca od žena, pri čemu se radilo o oblastima u kojima je boravilo više vojske, u koje je zbog privrednih razloga (posao u industriji ili rudarstvu) stizalo više muškaraca ili odakle je migracija žena bila izraženija. Iz sličnih razloga i u gradovima je postojao uravnoteženiji odnos među polovima $-\mathrm{u}$ 
zemaljskom proseku u gradovima na 1.000 muškaraca dolazilo je u proseku 1.005 žena, a u županijama 1.021 (Msk, 1912: 3*).

Što se tiče županija na tlu današnje Vojvodine možemo konstatovati da u Bačko-Bodroškoj i u Torontalskoj županiji prekobrojnost žena nije dostizao zemaljski županijski prosek (1.019 i 1.017 žena na 1.000 muškaraca), kao i da je u Sremskoj županiji živelo više muškaraca od žena (na 1.000 dolazilo je svega 972 žena). Od vojvođanskih municipalnih gradova u Zemunu, Pančevu i Subotici bilo je manje žena od muškaraca $(859,973$ i 998 žena na 1.000 muškaraca), dok je u Novom Sadu (1.048), Somboru (1.038) i Vršcu (1.026) postojao disbalans u korist žena (Msk, 1912: 28*).

Što se tiče starosne strukture stanovništva Ugarske, jedva da je bilo razlike u odnosu na prethodni zemaljski popis. Ono što je ipak vidljivo, bilo je povećanje srazmere žitelja iznad 60 godina (sa 7,6\% na 8,2\%) i smanjenje broja dece ispod 6 godina (sa $16,0 \%$ na $15,5 \%$ ). Prvo je bilo u vezi sa poboljšanjem higijenskih i zdravstvenih uslova života, a drugo sa smanjenjem broja novorođene dece. U smislu starosne strukture bilo je dosta razlike u gradovima u odnosu na zemaljski prosek i u odnosu na županije. Produktivno stanovništvo (20-39 godine života) u županijama bilo je zastupljeno sa $26,5 \%$, a u gradovima sa $36,2 \%$, štaviše u industrijski najrazvijenijim gradovima taj odnos je bio viši, npr. u Budimpešti iznosio je 41\% (Msk, 1912: 4*).

U vezi sa srazmerom produktivnog stanovništva podaci popisa svedoče o tome da su Bačko-Bodroška, Torontalska i Sremska županija bile blago iznad ugarskog proseka županija, ali i da su se svi vojvođanski municipalni gradovi nalazili ispod ugarskog proseka gradova (Msk, 1912: 31*-32*).

Po pitanju strukture porodičnog statusa jedva da ima razlike 1910. godine u poređenju sa onim iz 1900. godine: procenat neoženjenih i neudatih bio je 53,6\%, srazmera onih u bračnoj zajednici u oba popisa iznosila je 40,2\%; odnos udovica i udovaca bio je 6,2\%, a razvedenih 0,2\% (u apsolutnim brojevima 39.342). U Baranji koja je bila poznata po običaju ranog stupanja u brak procenat oženjenih/udatih iznosio je rekordnih 49,7\%, a u Ličko-Krbavskoj županiji, odakle je emigracija bila izrazita, iznosila je svega $34,2 \%$. Zapravo, negativan uticaj iseljavanja uočljiv je i na široj skali: broj brakova smanjen je u onim oblastima iz kojih je bilo najviše emigranata. I u ovom slučaju konstatovana je razlika između gradova i županija: bilo je znatno više neudatih/neoženjenih, a znatno manje bračnih parova u gradovima nego u provincijskom delu zemlje (Msk, 1912: 5*).

U vojvođanskim županijama postojala je dobra volja za sklapanjem brakova primetno iznad proseka, a do razvoda je u Torontalskoj i Sremskoj županiji dolazilo u meri koja se podudarala sa ugarskim prosekom, a u Bačko-Bodroškoj čak 
ispod proseka. Od gradova u Subotici, Somboru i Vršcu srazmera lica u bračnoj zajednici bila je iznad zemaljskog proseka, dok je u Pančevu, Novom Sadu, Temišvaru i naročito u Zemunu (34,9\%) bio ispod proseka. Po pitanju razvoda prednjačili su Pančevo, Zemun (u oba slučaja $0,8 \%$ ), za kojima su sledili Temišvar i Novi Sad (0,4\%), Sombor (0,3\%), Vršac $(0,2 \%)$ i Subotica (0,1\%) (Msk, 1912: 33*_ $34 *)$.

\section{ETNIČKA PRIPADNOST STANOVNIŠTVA}

U popisu iz 1910. godine nije traženo izjašnjavanje po nacionalnoj osnovi, već o maternjem jeziku, a maternjim jezikom se smatrao ,jezik koji smatrate vašim, jezik koji najradije i najčešće koristite“ (Buday, 1911: 465). Ti podaci su najbliži, iako po svoj prilici ne i podudarni, sa etničkom pripadnošću stanovnika. U obzir su uzimani samo živi jezici, a pošto hebrejski nije smatran takvim, hebrejski jezik nije bilo moguće upisati kao maternji. ${ }^{10}$ Teškoće za precizno utvrđivanje etničke strukture stanovništva stvara i okolnost da popis nije vršen po istoj metodologiji na nivou cele Austro-Ugarske, barem kada se radi o stanovništvu sa srpskim i hrvatskim maternjim jezikom. U Ugarskoj je razlikovan srpski od hrvatskog jezika, a u austrijskom delu Srbi i Hrvati su podvođeni pod kategoriju stanovnika sa srpskohrvatskim maternjim jezikom.

1. Tabela. Struktura stanovništva Ugarske po maternjem jeziku prema popisu

stanovništva iz 1910. godine

\begin{tabular}{|l|c|c|c|c|c|c|c|c|c|}
\hline & MADARSKI & NEMAČKI & SLOVAČKI & RUMUNSKI & RUSINSKI & HRVATSKI & SRPSKI & OSTALO & UKUPNO \\
\hline MADARSKA & 9.944 .627 & 1.903 .357 & 1.946 .357 & 2.948 .186 & 464.270 & 194.808 & 461.516 & 401.412 & 18.264 .533 \\
\hline $\begin{array}{l}\text { HRVATSKA I } \\
\text { SLAVONIJA }\end{array}$ & 105.948 & 134.078 & 21.613 & 846 & 8.317 & 1.638 .354 & 644.955 & 67.843 & 2.621 .954 \\
\hline UKUPNO & 10.050 .575 & 2.037 .435 & 1.967 .970 & 2.949 .032 & 472.587 & 1.833 .162 & 1.106 .471 & 469.255 & 20.886 .487 \\
\hline
\end{tabular}

10 Štaviše, detaljno uputstvo propisuje da kod „,...osoba jevrejske veroispovesti koji u pojedinim oblastima zemlje koriste mešanjem sa hebrejskim iskvareni nemački jezik, tzv. žargon, maternjim jezikom treba naznačiti nemački“ (Msk 1911, 497). 
1. Dijagram Struktura stanovništva Ugarske po maternjem jeziku prema popisu iz 1910. godine, izražena u procentima

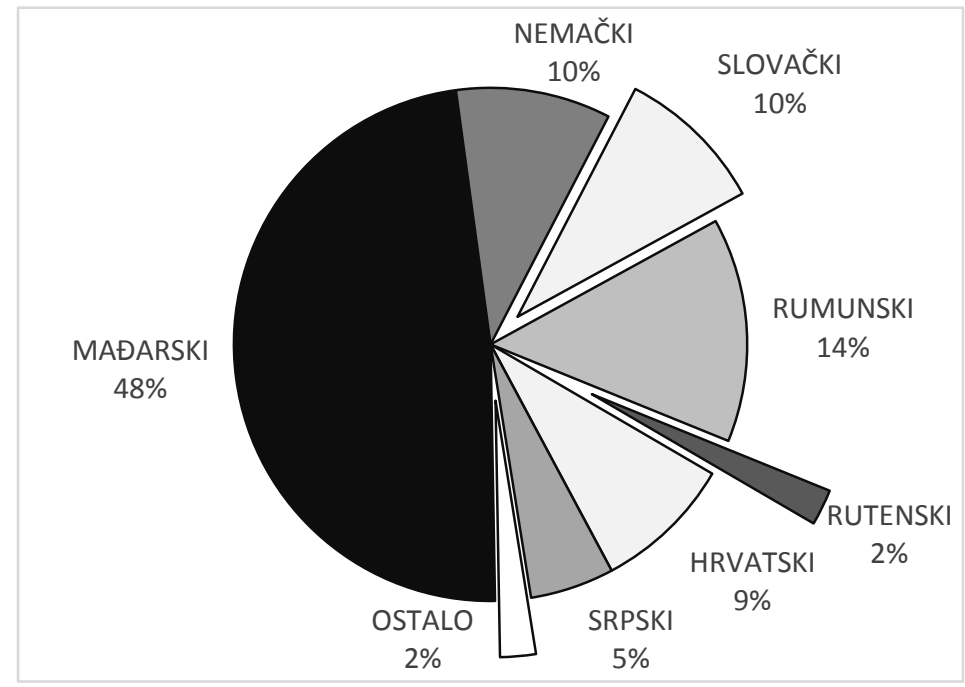

$\mathrm{Na}$ osnovu gornje tabele i dijagrama vidi se da su nešto više od $48 \%$ stanovnika Ugarske činili žitelji mađarskog maternjeg jezika. Pri tome bez hrvatskoslavonskih oblasti, u samoj Mađarskoj, Mađari su činili apsolutnu većinu od 54,5\%. Takođe je uočljivo, da su približno tri četvrtine stanovnika činili činili su narodi ne slovenskog porekla: Mađari, Rumuni i Nemci - za razliku od austrijskog dela Monarhije u kojoj su Sloveni činili više od 60\% stanovnika. Slično, u austrijskom delu Monarhije nemački je maternjim jezikom smatrao manji deo stanovništva nego mađarski u Ugarskoj (35,6\%). U Ugarskoj posle Mađara, Rumuna i Nemaca najbrojniji su bili Slovaci, Hrvati pa Srbi, dok su 2\% stanovnika činili manje jezičke zajednice, pre svega Roma (121 hiljada), Bunjevaca, Šokaca, Dalmatinaca, Bošnjaka (93 hiljada), Venda i Slovenaca (88 hiljada), Čeha i Moravljana (64 hiljada), Poljaka (41 hiljada), Italijana (33 hiljade), Bugara (23 hiljada) i drugih (npr. Turaka 306 i Grka 194) (Msk 1916, 117-120).

Pri razmatranju jezičke strukture stanovništva ne smemo smetnuti s uma, da su austrougarski Jevreji svojim maternjim jezikom označavali mađarski, nemački ili eventualno neki drugi jezik. O njihovom brojnom stanju svedoče rezultati popisa na osnovu verske pripadnosti, koji konstatuju 932.458 judaista (odnosno izraelita po onovremenoj terminologiji) u Ugarskoj i njih 1.313 .698 u Austriji (Msk, 1912: 5*, 8*, Kks, 1912: 54*). Ta okolnost upućuje na postojanje populacije sa dvostrukim identitetom, sa vezivanjem istovremeno za dve etničke i kulturne zajednice: u slučaju 
Austrije možemo razmišljati o jevrejsko-nemačkom u slučaju Ugarske o jevrejskomađarskom identitetu.

Upoređujući jezičke podatke popisa sa onima iz 1900. godine uočava se nekoliko glavnih tendencija. Pre svega, uočljiv je porast srazmere Mađara od 15\%, što je znatno prelazilo zemaljski prosek realnog uvećanja stanovnika u istom razdoblju. Natprosečan rast primećujemo još samo kod Rusina i Hrvata (ovih poslednjih samo na teritoriji Slavonije i Hrvatske). Broj Srba i Rumuna povećavao se ispod proseka (5,5\% i 5,3\%), a broj Nemaca i Slovaka se smanjio. Izričit porast jezičkih zajednica podvedenih pod ostalo (18\%) samo je delimično u vezi sa stvarnim rastom njihovog broja, a više u vezi sa poboljšanim metodama popisa i s time, da su Romi uopšteno, Poljaci u županiji Arva, a Šokci u Baranji puno tačnije prebrojani nego ranijih godina. U stvarnosti prirast tih etničkih zajednica bio je dosta nizak (Msk, 1912: 5*).

Popisu savremeni mađarski statističari, političari i sama javnost bili su prijatno iznenađeni značajnim uvećanjem broja i srazmere Mađara u stanovništvu zemlje: od ukupnog prirasta stanovništva u Ugarskoj $80 \%$ otpadalo je na Mađare; od šezdeset tri mađarske županije Mađari su imali apsolutnu većinu u trideset, a relativnu većinu u još četiri županije; udeo Mađara je u Ugarskoj sa 45,4\% 1910. godine porastao na $48,1 \%$, a u samoj Mađarskoj sa $51,4 \%$ na $54,5 \%$. Takav, troprocentni porast udela Mađara nije zabeležen od 1880. kada se u popisima počeo iskazivati sastav stanovništva po maternjem jeziku. U ugarskim municipalnim gradovima srazmera Mađara se sa 69,1\% popela na 73,7\% (Msk, 1912: 6*).

Posmatrano po regijama možemo konstatovati da je broj i udeo Mađara najviše rastao na levoj obali Dunava, u međurečju Dunava i Tise (tu je porastu znatno doprinela asimilacija velikog broja Nemaca u Budimpešti i njenoj okolini). Od municipija najveći porast zabeležen je u Zemunu (164,4\%), u županiji Turoc $(154,6 \%)$ i u Rijeci $(128,5 \%)$. Sem ovih bilo je još deset municipija gde je srazmera Mađara za deset godina porasla 50-100 odsto. Popis beleži i od glavne tendencije suprotne promene: u šest municipija (Baja, Hodmezevašarhelj, Kečkemet, Bihar, Haromsek, u županiji Maroš-Torda) došlo je do smanjenja srazmere Mađara u ukupnom stanovništvu (Msk, 1912: 6*-7*).

Konstatovani veliki porast broja mađarskih žitelja u periodu 1900-1910. objašnjava se sa nekoliko okolnosti. Jedan od značajnih uzroka bila je činjenica da je u posmatranom razdoblju prirodni prirast Mađara bio veći od drugih naroda. Određenu ulogu igrao je i srazmerno veći obim prekomorskog ekonomskog iseljavanja Nemaca i Slovaka od Mađara. Dalje, važnu stavku čini dobrovoljna asimilacija pripadnika nemađarskih narodnosti, pre svega u gradovima, gde su se među Mađare pretežno asimilovali Jevreji, Nemci i Slovaci. Sem gradova asimilacija 
pripadnika nemađarskih narodnosti odigravala se u oblastima sa pretežno mađarskom većinom i na etnički mešovitim oblastima, dok gotovo da i nije postojala (ili je čak imala obrnuti smer) u oblastima sa pretežno nemađarskim stanovništvom. Važno je imati na umu, kako su se Jevreji u jezičkom smislu u posmatranom razdoblju asimilirali pre svega među Mađare, a u manjoj meri među Nemce (Msk, 1912: 6*, $8^{*}$ ). S druge strane, Nemci su u Mađarskoj u prvim godinama dvadesetog veka beležili pad od gotovo sto hiljada duša, pri čemu pretpostavljamo da je sem smanjenog prirodnog priraštaja Nemaca i njihove prekomorske emigracije, tome kumovala i okolnost da je određen broj Jevreja umesto nemačkog počeo da se izjašnjava u korist mađarskog maternjeg jezika. Slično Nemcima i broj Slovaka se za deset godina smanjio - na ispod dva miliona. Pri tom je njihov broj u nekim municipijama, ipak, rastao (Vršac, Pančevo, Đer, Mošon, Silađ, Bihar, županija Torontal) (Msk, 1912: 7*).

Popis pruža dosta zanimljivu sliku o jezičkoj strukturi stanovništva današnje Vojvodine. Pri analizi smo se ograničili na podatke vojvođanskih municipija, bez svođenja podataka popisa na današnju teritoriju AP Vojvodine: tri županije i šest municipalnih gradova. Ti gradovi su u popisu izdvojeni iz teritorija županija na kojima su se inače nalazile. Obuhvaćena teritorija je od današnje AP Vojvodine, ali ipak, pokriva pretežan njen deo i obuhvatala je 1910. godine ukupno 1.848 .108 stanovnika. Svesni smo da zbog razlike u teritorijalnom opsegu podaci ne oslikavaju potpuno tačnu situaciju na današnjim prostorima Vojvodine, ali svakako pružaju uvid u glavne karakteristične crte etničkih odnosa toga doba.

2. Tabela. Struktura stanovništva vojvođanskih municipija po maternjem jeziku 1910. godine (Msk, 1912: 35*-36*)

\begin{tabular}{|c|c|c|c|c|c|c|c|c|c|}
\hline & MAĐARSKI & NEMAČKI & SLOVAČKI & RUMUNSKI & RUSINSKI & HRVATSKI & SRPSKI & DRUGI & UKUPNO \\
\hline$B A \check{C} K O-B O D R O \check{S} K A \check{Z}$. & 267.714 & 178.950 & 28.501 & 189 & 10.400 & 520 & 117.854 & 28.432 & 632.560 \\
\hline TORONTALSKA Ž. & 125.041 & 158.312 & 15.899 & 86.168 & 10 & 4.068 & 191.036 & 13.809 & 594.343 \\
\hline SREMSKA Ž. & 27.523 & 61.527 & 13.706 & 511 & 4.634 & 103.998 & 177.456 & 7.748 & 397.103 \\
\hline SUBOTICA & 55.587 & 1.913 & 100 & 60 & 7 & 39 & 3.514 & 33.390 & 94.610 \\
\hline NOVI SAD & 13.343 & 5.918 & 1.453 & 83 & 332 & 621 & 11.594 & 246 & 33.590 \\
\hline SOMBOR & 10.078 & 2.181 & 38 & 28 & 15 & 83 & 11.881 & 6.289 & 30.593 \\
\hline$V R \check{S} A C$ & 3.890 & 13.556 & 127 & 879 & 9 & 38 & 8.602 & 269 & 27.370 \\
\hline PANČEVO & 3.364 & 7.467 & 244 & 769 & 1 & 135 & 8.714 & 114 & 20.808 \\
\hline ZEMUN & 1.999 & 6.559 & 135 & 76 & 8 & 2.200 & 5.653 & 501 & 17.131 \\
\hline UKUPNO & 508.539 & 436.383 & 60.203 & 88.763 & 15.416 & 111.702 & 536.304 & 90.798 & 1.848.108 \\
\hline
\end{tabular}


Ukoliko posmatramo prosek pomenutih samoupravnih teritorija dobijamo impresivnu sliku. Pripadnici tri naroda, Srbi, Mađari i Nemci činili su 80\% stanovnika vojvođanskih oblasti, pri čemu je njihova srazmera u ukupnom broju stanovnika bila istog reda veličine i kretala se od 24 do 29 odsto. Druga konstatacija jeste da su neslovenski narodi činili barem 56\% stanovnika, a razni slovenski oko $44 \%$ stanovnika, što je više išlo u prilog slovenskim narodima od udela u celokupnom stanovništvu Ugarske (28\%). U odnosu na zemaljski prosek, na vojvođanskim prostorima bila je znatno veća srazmera Nemaca i Srba, a dosta manji udeo Mađara, Rumuna i Slovaka. Prisustvo Jevreja u jezičkoj strukturi nije vidljivo, kao ni postojanje prilično velikog broja bačkih, subotičkih i somborskih Bunjevaca i Šokaca - koji su sakriveni unutar kategorije „drugi“. No i bez toga je očito, da je regija imala izrazito višenacionalni karakter sa dominantnom ulogom Srba, Mađara i Nemaca (i dodajmo - Jevreja) u njenom društvenom, privrednom političkom i kulturnom životu (Msk, 1912: 35*-36*).

2. Dijagram. Struktura stanovništva teritorije današnje Vojvodine po maternjem jeziku, na osnovu podataka popisa stanovništva iz 1910. godine (Msk, 1912: 35*_ $\left.36^{*}\right)$.

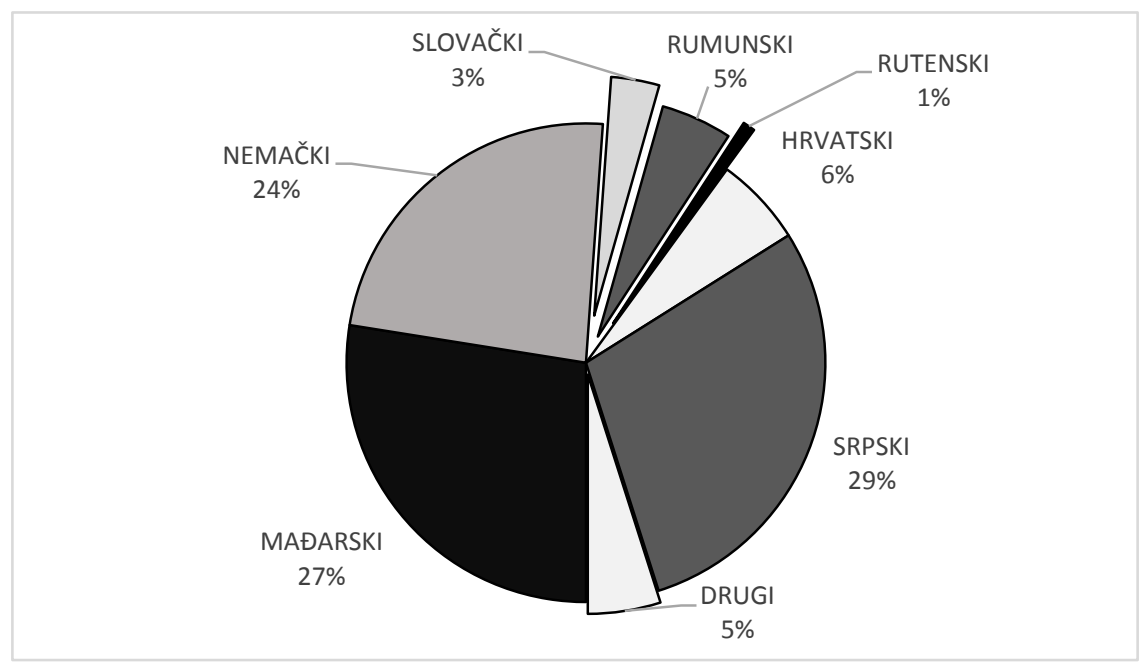

Na osnovu donjih dijagrama jasno je uočljivo koliko su pojedine oblasti koje čine današnju Vojvodinu u jezičko-etničkom smislu bile različite. Bačka je imala mađarsku relativnu većinu (42\%), pri čemu su oni zajedno sa Nemcima činili nešto više od $70 \%$ stanovnika. Značajan je bio udeo Srba u stanovništvu, a primetna je i srazmera Slovaka, Rusina i "drugih" koja je prevazilazila njihov udeo u stanovništvu 
ostalih županija. Torontalska županija pokazuje donekle drugačiju sliku. Ona je imala najviše ravnomernu etničku strukturu: iako su Srbi činili relativnu većinu od 32\%, Nemci, Mađari i Rumuni su takođe bili zastupljeni u znatnoj srazmeri i činili su ukupno preko $60 \%$ stanovnika. Oblast sa slovenskom većinom predstavljala je Sremska županija: Srbi su činili relativnu većinu od $45 \%$, a značajnu jezičko-etničku zajednicu predstavljali su Hrvati (26\%). U Sremskoj županiji egzistiralo je relativno značajno stanovništvo sa nemačkim maternjim jezikom (15\%) i najmanja zajednica Mađara od svih županija (7\%). Slovaci su bili primetni u svim županijama, dok su Rumuni u većem broju živeli samo u Torontalskoj županiji (Msk, 1912: 35*-36*).

3. Dijagram. Struktura stanovništva vojvođanskih županija po maternjem jeziku 1910. godine (Msk, 1912: 35*-36*).

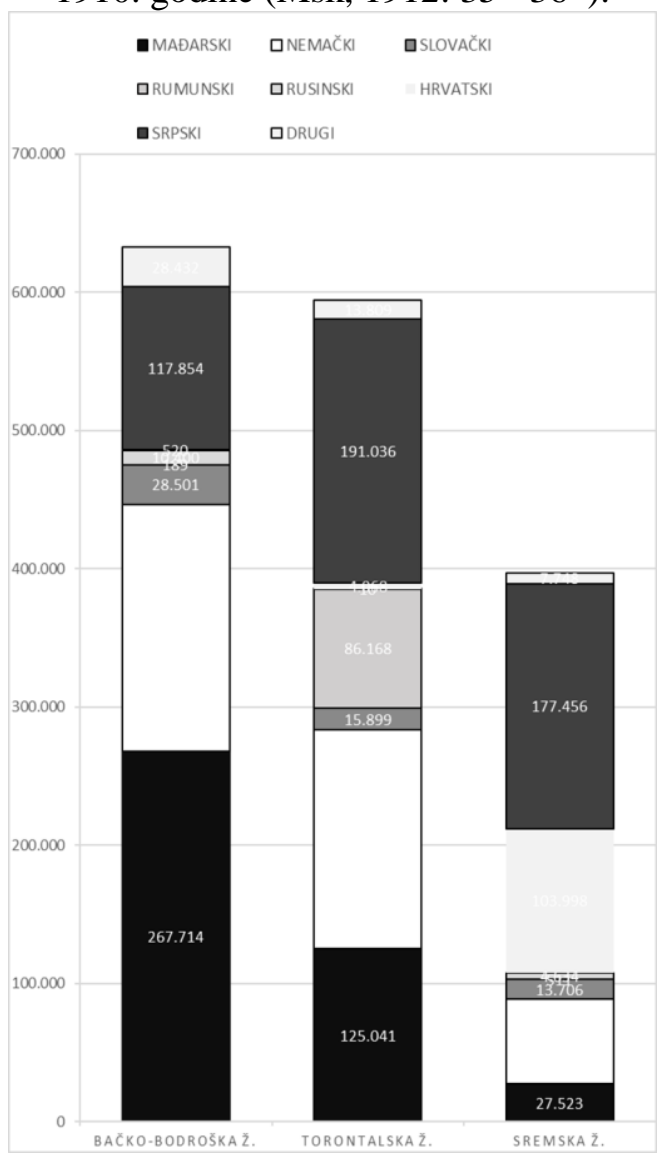

Dvanaest posto, odnosno, 224.102 duša sa posmatranih vojvođanskih oblasti živelo je u 6 municipalnih gradova (12,1\%). Od tog broja preko osamdeset osam 
hiljada bili su Mađari i gotovo pedeset hiljada Srbi. Karakteristična crta municipalnih gradova bila je okolnost da je sem Sombora, u ostalim gradovima nemačko-mađarsko stanovništvo dostizalo ili prelazilo $50 \%$. Mađari su predstavljali preko $30 \%$ stanovnika nekadašnjih kraljevskih gradova Subotice, Sombora i Novog Sada, dok su u ostalim municipijama bili zastupljeni sa udelom između deset i dvadeset odsto. Srbi su sem Subotice, svugde živeli u srazmeri koja je prelazila 30\%, u Somboru i Zemunu njihov udeo se kretao oko $40 \%$. Nemaca je u Zemunu i Pančevu bilo u srazmeri od oko 30\% u Vršcu blizu 40\%, a u kraljevskim gradovima u manjem procentu od spominjanih (Msk, 1912: 35*-36*).

4. Dijagram. Struktura stanovnika vojvođanskih municipalnih gradova 1910. godine (Msk, 1912: 35*-36*).

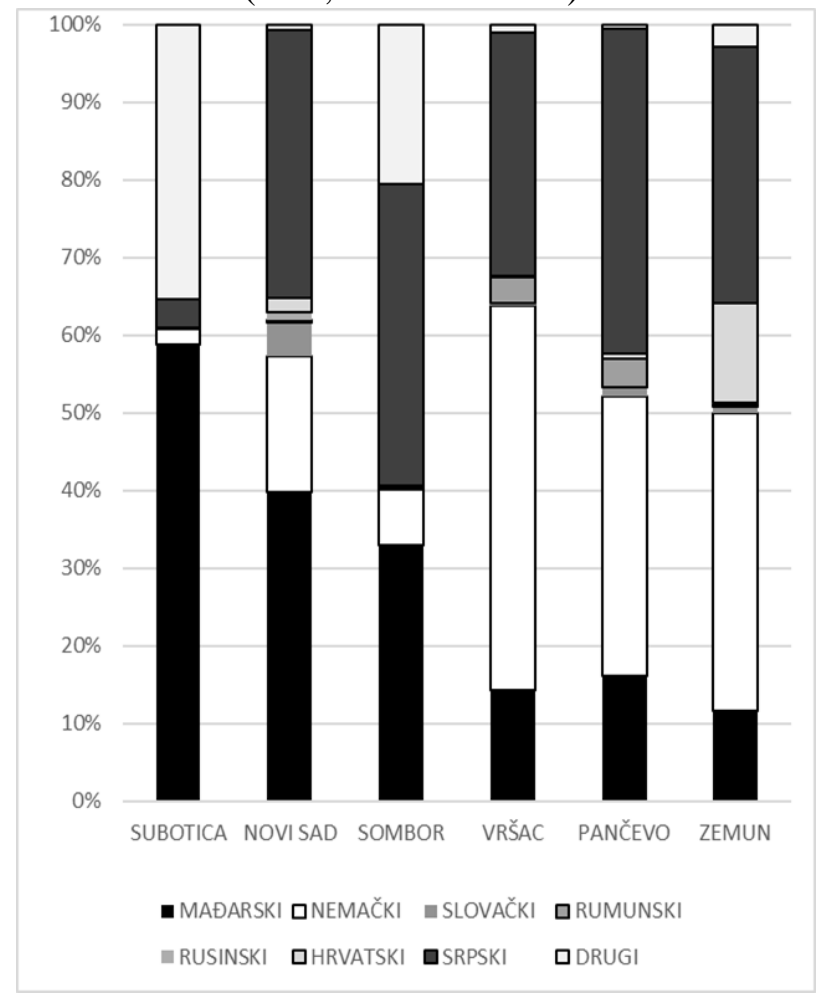

Zadovoljstvo mađarske javnosti, uzrokovano porastom srazmere Mađara u ukupnom stanovništvu Ugarske, donekle je pomutilo pitanje udela onih koji su iz redova nemađarskih naroda govorili mađarski jezik: svega 1.939 .987 (17,9\% na 
nivou Ugarske, a bez hrvatsko-slavonskih oblasti 22,5\%) (Msk, 1912: 7*). ${ }^{11}$ Pomalo iznenađuje činjenica da pretežna većina nemađarskih stanovnika Mađarske nije smatrala neophodnim znanje mađarskog jezika za život u Mađarskoj. Utoliko više, da je taj jezik bio i službeni jezik Mađarske i da je 18. zakonski članak iz 1879. godine propisivao uvođenje mađarskog jezika kao predmeta u školama sa nemađarskim nastavnim jezikom; odnosno propisivao je da svi nastavnici u nemađarskim narodnim školama imaju obavezu da nauče mađarski jezik. Čini se da taj zakon nije striktno sprovođen, s obzirom da je 11 godina kasnije bilo još preko 2.000 nastavnika koji nisu poznavali službeni jezik države i 2.400 narodnosnih škola u kojima učenje mađarskog jezika nije doneo gotovo nikakav rezultat. Pokazalo se da je učenje mađarskog bilo efikasno samo u gradovima ili u mešovitim sredinama u kojima su učenici imali priliku da se u svakodnevnom životu sretnu sa mađarskim jezikom. U pretežno nemađarskim regijama gde to nije bio slučaj, deca i nisu naučila mađarski jezik (Katus 2015). Podaci popisa upravo potvrđuju ovu konstataciju: poznavanje mađarskog jezika bilo je u srazmeri sa mogućnošću živog kontakta s tim jezikom. Ovakvo stanje pak dovodi u pitanje konstataciju o sprovođenju nasilne mađarizacije u doba dualizma. Istina, mađarski onovremeni analitičari su voleli isticati određeni napredak u poznavanju mađarskog jezika u odnosu na podatke prethodnog popisa stanovništva: tada je u Mađarskoj mađarski jezik poznavalo 16,9\% pripadnika nemađarskih narodnosti, a na nivou Ugarske 13,5\%. Pada u oči nizak odnos poznavalaca mađarskog jezika u hrvatskim oblastima (2,6\% 1910. godine) - što je verovatno u vezi sa činjenicom da je učenje mađarskog jezika u Hrvatskoj i Slavoniji bilo moguće samo u ličnom kontaktu sa poznavaocima mađarskog - pošto se $u$ školama nije učio (Msk, 1912: 7*).

Srazmera onih koji su u Ugarskoj 1910. govorili mađarski, bilo kao maternji bilo kao jezik društvene sredine, za deset godina porastao je za 4,5\% (sa 52,9\% na 57,4\%), što ipak nije bez značaja. Industrijska zanimanja, uslužne delatnosti, izražen kulturni život, intenzivniji društveni život i mađarska društvena okolina učinili su da je u municipalnim gradovima taj odnos bio daleko veći: $85,1 \%$ i bila su samo tri grada (Rijeka, Vršac i Pančevo) u kojima poznavaoci mađarskog jezika nisu bili u apsolutnoj većini. Primetimo, da je u Rijeci broj onih koji su govorili mađarski jezik za deset godina porastao sa 4.595 čak na 10.737 (Msk, 1912: 7*-8*).

${ }^{11} \mathrm{U}$ rubriku pod naslovom „Jezici koje govorite sem vašeg maternjeg” trebalo je uneti jezike koje je ispitanik govorio na nivou koji je bio dovoljan da vodi razumljivu komunikaciju sa osobama drugog maternjeg jezika, u skladu sa svojim životnim okolnostima (Msk 1911, 497). 
3. Tabela. Poznavanje mađarskog jezika u vojvođanskim oblastima 1910. godine (Msk, 1912: 42*-43*)

\begin{tabular}{|c|c|c|c|c|c|c|c|c|c|}
\hline & \begin{tabular}{|c|}
$B A \tilde{C} K O-$ \\
BODROŠKA \\
$\tilde{Z}$.
\end{tabular} & $\begin{array}{c}\text { TORONTALSKA } \\
\check{Z} .\end{array}$ & $\begin{array}{c}\text { SREMSKA } \\
\check{Z} .\end{array}$ & SUBOTICA & $\begin{array}{l}N O V I \\
\text { SAD }\end{array}$ & SOMBOR & $V R \check{S} A C$ & PANČEVO & ZEMUN \\
\hline \begin{tabular}{|c|} 
GOVORI \\
MAĐARSKI
\end{tabular} & 56,8 & 36,5 & 10,8 & 80,4 & 64,5 & 52,2 & 39,5 & 44,1 & 21,8 \\
\hline \begin{tabular}{|c|} 
NEMAĐARI \\
KOJI \\
GOVORE \\
MAĐARSKI
\end{tabular} & 24,2 & 19,5 & 4,2 & 52,6 & 41,1 & 28,8 & 29,5 & 33,4 & 10,9 \\
\hline
\end{tabular}

Mala srazmera pripadnika nemađarskih narodnosti koji govore službeni jezik države karakterisala je i vojvođanske oblasti: $U$ Bačko-bodroškoj i Torontalskoj županiji kretao se oko proseka Mađarske, a u Sremskoj županiji, koja je pripadala Hrvatskoj, taj odnos je bio izrazito nizak. Slična je bila situacija u vojvođanskim gradovima u kojima je poznavanje mađarskog bilo ispod mađarskog proseka. Mađarski savremenici su se mogli samo tešiti činjenicom, da je u odnosu na 1900-tu godinu u svakoj municipiji ipak vidljivo širenje poznavanja mađarskog jezika od nekoliko postotaka (Msk, 1912: 42*-43*).

\section{RELIGIJSKA PRIPADNOST STANOVNIŠTVA}

U pogledu verske strukture stanovništva Ugarske nema primetnijih promena u odnosu na stanje iz 1900-te godine, štaviše rezultati popisa potvrđuju tendenciju koja je bila uočljiva od ranijih popisa. Konkretnije, reč je o blagom povećanju udela rimokatolika, grko-katolika i judaista u ukupnom stanovništvu, pri čemu je srazmera drugih veroispovesti bila u opadanju - pre svega luterana i pravoslavnih. Te promene bile su uzrokovane različitim stepenom prirodnog priraštaja, rastom broja mešovitih brakova, prelascima s jedne na drugu konfesiju, ali i posledicama ekonomske emigracije u SAD (Msk, 1912: $8^{*}$ ). Sem ugla Moriša i Tise i desne obale Tise, odakle su se brojni nemački rimokatolici iselili, srazmera katolika je bila u veoma blagom porastu u celoj Ugarskoj. Na zemaljskom nivou udeo Jevreja u ukupnom broju vernika se uvećavao, pri čemu je popis konstatovao njihovo snažno kretanje ka gradovima. Usled tog procesa u županijama je u proseku njihov procenat opadao, štoviše, u nekim oblastima (zapadna Ugarska, Alfeld) vidljivo je i smanjenje apsolutnog broja Jevreja. Kod kalvinista popis takođe beleži intenzivnu migraciju prema gradovima, gde se njihova srazmera od 1900. g. povećala čak više nego srazmera Jevreja. S druge strane, gotovo u svim županijskim oblastima Mađarske udeo kalvinista se smanjivao. Srazmera luterana se takođe smanjivala, ali u njihovom slučaju umanjenje je bilo izrazitije u 
gradovima nego u županijama. Pravoslavni su u odnosu na 1900-tu godinu ojačali svoje pozicije na levoj obali Tise, ali je njihova srazmera blago opala na desnoj obali te reke, kao i u međurečju Dunava i Tise i u Erdelju, a u gradovima su zadržali svoje ranije položaje (Msk, 1912: 8*-9*).

4. Tabela. Broj pripadnika pojedinih konfesija Ugarske prema popisu iz 1910. godine

\begin{tabular}{|l|c|c|c|c|c|c|c|c|}
\hline & $\begin{array}{c}\text { KATO- } \\
\text { LIKA }\end{array}$ & $\begin{array}{c}\text { GRKO- } \\
\text { KATOLIKA }\end{array}$ & $\begin{array}{c}\text { KALVI- } \\
\text { NISTA }\end{array}$ & $\begin{array}{c}\text { EVANGE- } \\
\text { LIKA }\end{array}$ & $\begin{array}{c}\text { PRAVOSLA- } \\
\text { VNIH }\end{array}$ & $\begin{array}{c}\text { UNITA- } \\
\text { RACA }\end{array}$ & $\begin{array}{c}\text { JEVRE- } \\
\text { JA }\end{array}$ & OSTALO \\
\hline MAĐARSKA & 9.010 .305 & 2.007 .916 & 2.603 .381 & 1.306 .384 & 2.333 .979 & 74.275 & 911.227 & 17.066 \\
\hline $\begin{array}{l}\text { HRVATSKA } \\
\text { I }\end{array}$ & 1.877 .833 & 17.592 & 17.948 & 33.759 & 653.184 & 21 & 21.231 & 386 \\
SLAVONIJA & & & & & & & & \\
\hline UKUPNO & 10.888 .138 & 2.025 .508 & 2.621 .329 & 1.340 .143 & 2.987 .163 & 74.296 & 932.458 & 17.452 \\
\hline
\end{tabular}

5. Dijagram. Srazmera pripadnika pojedinih konfesija u ukupnom stanovništvu Ugarske prema popisu iz 1910. godine

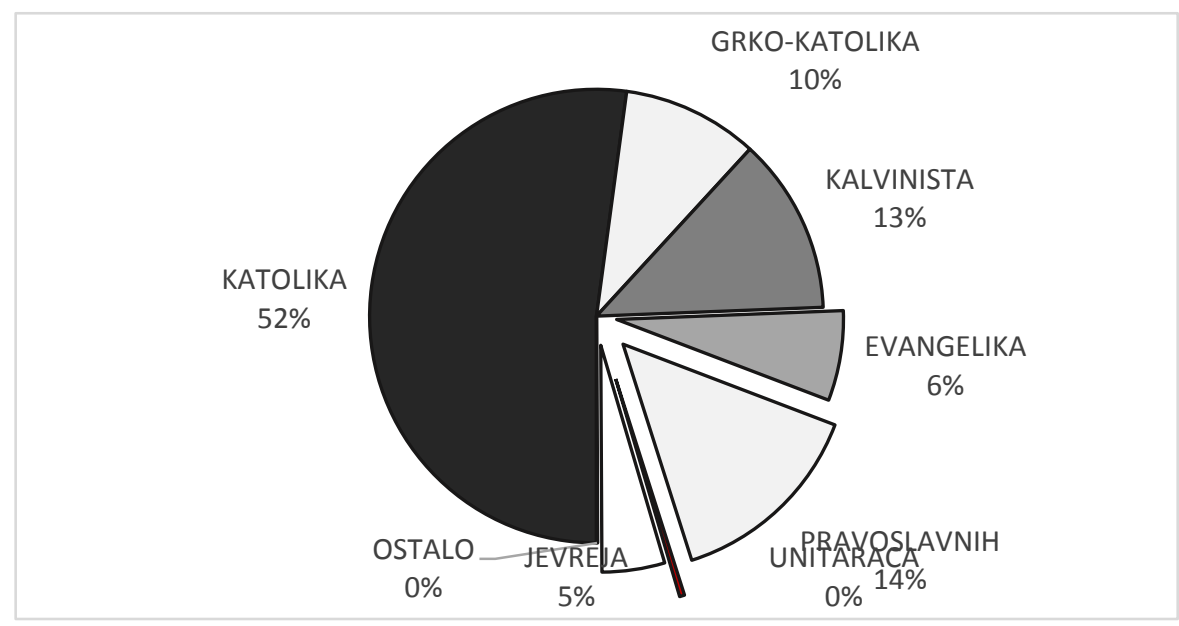

Verska struktura stanovništva teritorije današnje Vojvodine je u odnosu na ugarski prosek pokazivao određene lokalne specifičnosti. Pri tome i na vojvođanskim prostorima pretežan deo stanovništva činili su katolici, ali je srazmera grko-katolika bila primetno niža od ugarskog. Slično, u našim oblastima u proseku bilo je dosta manje kalvinista i luterana - u korist pravoslavnih, koji su sa $34 \%$ predstavljali drugu po veličinu versku zajednicu. Udeo Jevreja bio je višestruko niži od zemaljskog proseka (Msk, 1912: 44*-45*). 
6. Dijagram. Verska struktura vojvođanskog stanovništva 1910. godine (Msk, 1912: $\left.44 *-45^{*}\right)$.

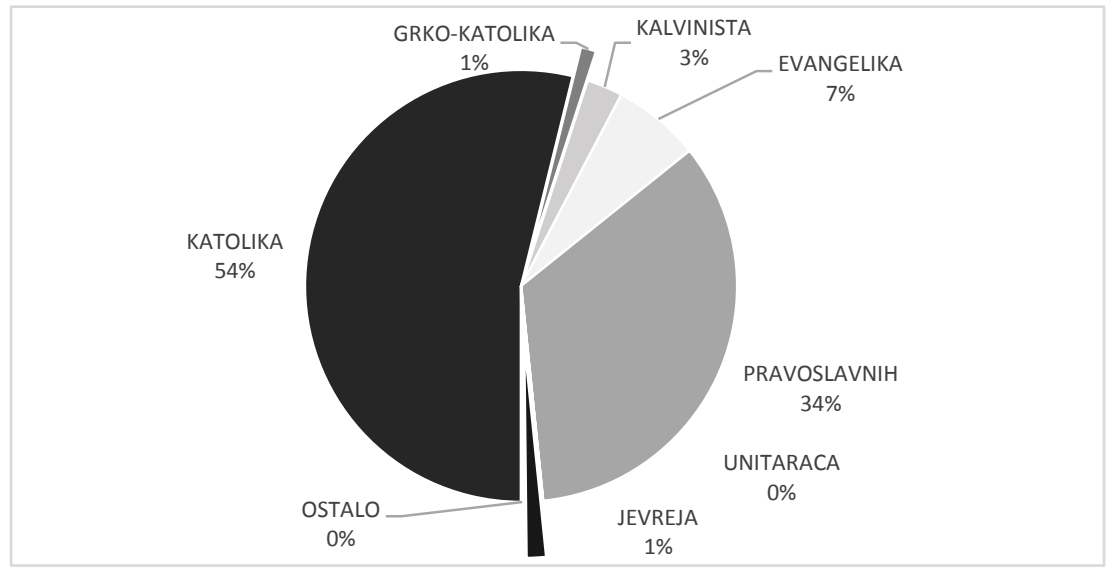

Posmatrajući verski sastav po vojvođanskim municipijama jasno se uočava katoličko-pravoslavni karakter uz primetno prisustvo protestanta i Jevreja. Pri tome ukupna srazmera katolika i protestanta svugde prelazi pedeset odsto. Najviše Jevreja u apsolutnim brojevima bilo je u Bačkoj i Torontalskoj županiji, a srazmerno ukupnom stanovništvu, u Novom Sadu, Subotici, Somboru, Pančevu i Zemunu.

5. Tabela. Religijska struktura vojvođanskog stanovništva 1910. godine (Msk, 1912: $43 * .44 *)$

\begin{tabular}{|l|l|l|l|l|l|l|l|l|l|}
\hline & $\begin{array}{l}\text { KATO- } \\
\text { LIKA }\end{array}$ & $\begin{array}{l}\text { GRKO- } \\
\text { KATOLIKA }\end{array}$ & $\begin{array}{l}\text { KALVI- } \\
\text { NISTA }\end{array}$ & $\begin{array}{l}\text { EVANGE- } \\
\text { LIKA }\end{array}$ & $\begin{array}{l}\text { PRAVOSLA- } \\
\text { VNIH }\end{array}$ & $\begin{array}{l}\text { UNITA- } \\
\text { RACA }\end{array}$ & $\begin{array}{l}\text { JEVRE- } \\
\text { JA }\end{array}$ & $\begin{array}{l}\text { OSTA- } \\
\text { LO }\end{array}$ & \\
\hline $\begin{array}{l}\text { BAČKO-BODROŠKA } \\
\text { Z. }\end{array}$ & 401.187 & 10.963 & 24.602 & 66.009 & 118.764 & 48 & 9.271 & 1.716 & 632.560 \\
\hline TORONTA-LSKA Ž. & 272.283 & 3.603 & 11.556 & 22.926 & 277.281 & 108 & 5.408 & 1.178 & 594.343 \\
\hline SREMSKA Ž. & 172.506 & 5.667 & 6.974 & 25.570 & 183.156 & 1 & 3.098 & 131 & 397.103 \\
\hline SUBOTICA & 85.445 & 152 & 1.420 & 511 & 3.486 & 6 & 3.539 & 51 & 94.610 \\
\hline NOVI SAD & 13.383 & 458 & 2.751 & 3.089 & 11.553 & 3 & 2.326 & 27 & 33.590 \\
\hline SOMBOR & 16.796 & 73 & 543 & 257 & 11.880 & 6 & 1.017 & 21 & 30.593 \\
\hline VRŠAC & 16.336 & 83 & 314 & 333 & 9.544 & 4 & 743 & 13 & 27.370 \\
\hline PANČEVO & 7.510 & 225 & 993 & 1.979 & 9.361 & 7 & 706 & 27 & 20.808 \\
\hline ZEMUN & 9.634 & 55 & 538 & 357 & 5.851 & 6 & 681 & 9 & 17.131 \\
\hline & 995.080 & 21.279 & 49.691 & 121.031 & 630.876 & 189 & 26.789 & 3.173 & 1.848 .108 \\
\hline
\end{tabular}


6. Dijagram. Konfesionalni sastav vojvođanskih municipija 1910. g. u procentima (Msk, 1912: 43*.44*).

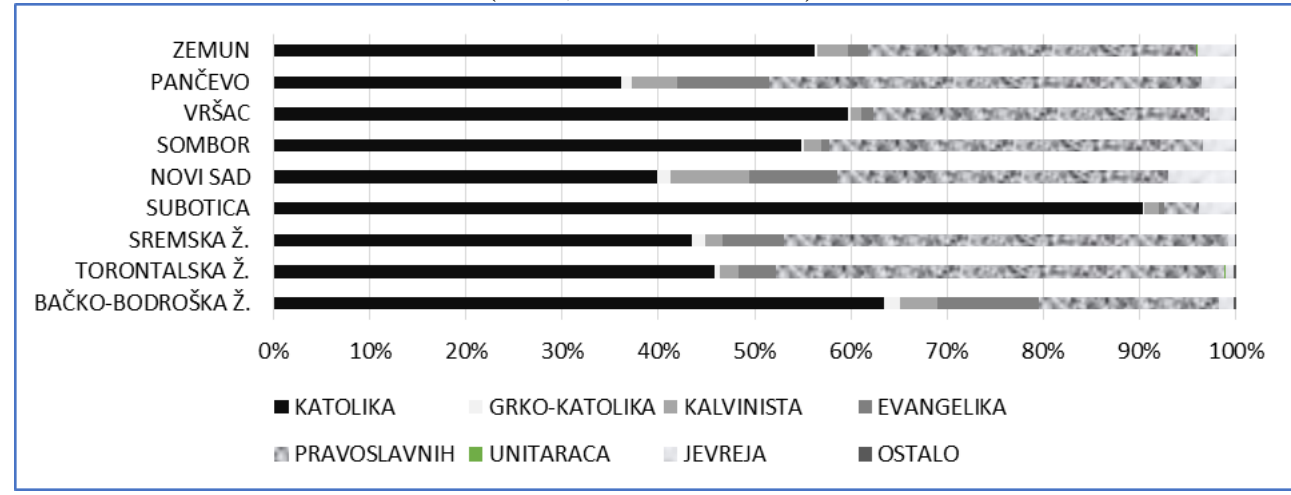

\section{OBRAZOVANOST STANOVNIŠTVA}

Najvažniji pokazatelj obrazovanosti stanovništva bio je i ostao nivo pismenosti. U tom smislu stanovništvo Ugarske je za deset godina primetno napredovalo. Iako je situacija po raznim regijama i gradovima Ugarske bila prilično šarena, ukupno 11.774 .697 pismenih (56,4\% ukupnog stanovništva) ipak je značio primetan rast (7\%) u odnosu na stanje 1900. godine. Bolja je srazmera pismenih u starosnoj kategoriji iznad 6 godina: 66,7\%, pri čemu su pismeni u Mađarskoj činili 68,7\%, a u Hrvatsko-slavonskom kraljevstvu dosta manje (52,6\%), iako je poboljšanje prema ranijem stanju $(44,4 \%)$ i ovde bilo vidno. Gradovi su i po pismenosti prednjačili sa $85,4 \%$ pismenih stanovnika iznad 6 godina starosti (županije 64,2\%). Najviše je bilo pismenih u Šopronu (95\%), a zatim u Budimpešti, Požunju, Sekešfehervaru, Đeru, Komaromu, itd. Na donjem delu lestvice nalazile su se Subotica i Sombor sa procentima nižim od zemaljskog proseka (61\% i 65\%) (Msk, 1912: 9*, 47*). Primetimo da je prosek municipalnih gradova izrazito visok po svoj prilici usled činjenice da je Budimpešta sa svojih 880.371 stanovnika u znatnoj meri podigla tu vrednost. Inače bi se ona verovatno kretala oko $80 \%$.

Od županija sa najviše pismenih bile su županije Šopron, Mošon (u oba po $88,9 \%$ pismenih iznad 6 godina), Baranja i Zala, a najniže čitanju i pisanju vičnih bilo je na levoj obali Tise i u županijama Maramaroš i Solnok-Doboka, sa vrednostima ispod $30 \%$, dok je najniža pismenost u celoj Ugarskoj postojala u Ličko-Krbavskoj županiji (25,1\%) (Msk, 1912: 9*). 
6. Tabela. Procentualni odnos pismenih u vojvođanskim municipijama 1900. i

1910. godine (Msk, 1912: 47*).

\begin{tabular}{|l|l|l|l|l|l|l|l|l|l|}
\hline & $\begin{array}{l}\text { BAČKO- } \\
\text { BODROŠKA } \\
\check{Z} .\end{array}$ & $\begin{array}{l}\text { TORONTALSKA } \\
\check{Z} .\end{array}$ & $\begin{array}{l}\text { SREMSKA } \\
\check{Z} .\end{array}$ & SUBOTICA & $\begin{array}{l}\text { NOVI } \\
\text { SAD }\end{array}$ & SOMBOR & VRŠAC & PANČEVO & ZEMUN \\
\hline $\begin{array}{l}\text { PISMENI } \\
\text { IZNAD 6 } \\
\text { GODINA } \\
\text { STAROSTI } \\
\text { 1900 u \% }\end{array}$ & 67 & 57,2 & 58,1 & 49,5 & 73,6 & 55,1 & 73,7 & 72,8 & 76,4 \\
\hline $\begin{array}{l}\text { PISMENI } \\
\text { IZNAD 6 } \\
\text { GODINA } \\
\text { STAROSTI } \\
\text { 1910 u \% }\end{array}$ & 73,7 & 64,7 & 66,6 & 61,1 & 78,2 & 64,7 & 76,8 & 74,8 & 83,5 \\
\hline
\end{tabular}

Što se tiče naših oblasti, možemo zaključiti da je tokom deset godina došlo do vidnog napretka. U svakoj municipiji srazmera pismenih primetno je porasla, pri čemu je napredak bio najveći u Subotici i Somboru. Značajan je bio rast u sve tri županije - u kojima je odgovarajući procenat prevazilazio ugarski prosek županija. Najsporiji rast beležen je u Pančevu i Vršcu, s time da nijedan vojvođanski grad nije dostizao zemaljski prosek gradova, iako se Zemun sasvim približio toj vrednosti. (Msk, 1912: 47*).

Obilazeći stanovništvo po kućama, popisivači su beležili broj kuća, kvalitet zidova i krovova. U odnosu na prethodni popis, zabeleženo je 332.000 novih kuća, što je čini se bilo u skladu sa porastom stanovništva, pošto je odnos stanovnika i kuća tokom deset godina ostao isti $(5,9)$. Generalno gledano, u odnosu na ranije decenije, primećivalo se vidno poboljšanje u korišćenoj građi za zidove i krovove, $\mathrm{u}$ rastu kvaliteta i složenosti građevina; poboljšavala se opšta gradska slika, prosečna visina zgrada je rasla - naročito su ulepšani centralni delovi gradova; počelo se sa izgradnjom komunalne infrastrukture (popločavaju se putevi, gradi se kanalizacija, gasna i vodovodna mreža, gradska rasveta, itd.). Javne zgrade poput škola, bolnica, kasarni, železničkih stanica zidane su obično u eklektičnom stilu, čime su pokazivale veliku sličnost sa zgradama u drugim delovima Monarhije. Ipak, uz sav progres, još su uvek preovlađivale kuća od naboja ili drva, sa krovom od slame ili trske, a tek $21 \%$ kuća građeno je od kamena i cigala, i njih $39 \%$ sa popločanim krovom (Hanák, 1983: 411, Msk, 1912: 9*-10*).

\section{ZAKLJUČAK}

Popis iz 1910. godine je pravo vrelo raznovrsnih podataka iz nekadašnjih ugarskih oblasti. Mogli bismo konstatovati da je njegovo istraživanje u našoj 
istoriografiji tek u početnoj fazi i da će buduće analize svakako iznedriti vredne priloge društvenoj i privrednoj istoriji.

Vreme nastanka popisa višestruko uvećava značaj samih sakupljenih podataka. Radilo se o popisu koji je od svih pređašnjih bio savremeniji, obuhvatniji, dublji i bogatiji. Beležio je stanje stanovništva i društva u vremenu najbližem raspadu mađarske države i ovekovečio je odnose i procese koji su bili karakteristični za Ugarsku u tom momentu - vidljive rezultate građanskog i industrijskog razvitka iz prethodnih decenija i brojne znake da ugarsko društvo $u$ isto vreme karakterišu brojne reminiscencije ranijih vremena, ali i modernog razvoja.

Popis je obuhvatao stanovništvo različite etničke i verske pripadnosti, sa različitim privrednim, društvenim i kulturnim preferencijama; obuhvatalo je stanovništvo u oblastima sa prilično različitim geografskim odlikama - počev od planinskih stočarskih oblasti na obroncima Karpata, sa raštrkanim selima, slabo povezanim sa drugim naseljima, do oblasti sa gustom mrežom mnogoljudnih sela sa dobrim saobraćajem i razgranatom železničkom mrežom. Bilo je regija sa pretežnom poljoprivrednom delatnošću, ali i gradova i varoši sa sve brojnijim industrijskim postrojenjima, rudnicima, sve više diferenciranim uslužnim delatnostima, pa i sa milionskim evropskim velegradom kakav je bila Budimpešta. Sve njih povezivao je zajednički državno-pravni okvir i viševekovni zajednički istorijski uslovi razvitka, manje-više zajednička sudbina. Čini nam se da istraživanje ovoliko raznovrsnog društva može predstavljati pravi izazov za naučnike različitog profila - pre svega iz aspekta istorijskog funkcionisanja složenih društava. Uz to, smatramo da bez poznavanja pomenutog ugarskog istorijskog okvira, gotovo da nije moguće razumeti brojne procese i pojave (demografske katastrofe izazvane epidemijama, ratovima, migratorna kretanja, razvoj mreže naselja i procese urbanizacije, interetničke i konfesionalne odnose, političke tendencije, itd.) karakteristične za pomenute narode u 19. i 20. veku.

Rezultati popisa pokazivali su kontinuitet demografskih i društvenih tendencija uočenih $u$ prethodnim decenijama. Proces urbanizacije, unutrašnje i spoljne migracije kao i promene društvene strukture bili su itekako vidljivi $\mathrm{u}$ rezultatima popisa. Generalno, popis je prikazao Ugarsku u razvoju: svi značajniji demografski pokazatelji važni u tom dobu (povećanje broja stanovnika, prirodni prirast stanovnika, gustina stanovništva, rast broja žitelja gradova, poboljšanje kvaliteta stanovanja, uvećanje srazmere Mađara i onih koji su poznavali mađarski jezik, stabilnost porodica, migracija prema gradskim centrima, primetno povećanje stanovnika u gradskim naseljima, snažna privlačna snaga Budimpešte, rast obima industrije, industrijske radne snage, uvećanje srazmere pismenih, sve izraženije 
razlike u strukturi stanovništva gradova i seoskih oblasti) svedočili su o uzlaznoj putanji ugarskog društva. Paralelno s tim, bilo je znakova koji su upućivali na ozbiljno razmišljanje i preduzimanje neophodnih državnih mera. Mislimo pri tome pre svega na posledice ekonomske emigracije koje su ostavljale sve markantnije tragove na brojnim demografskim aspektima (znatno snižavanje realnog rasta stanovništva, disbalans rodne strukture, diskretne izmene u etničkoj i verskoj strukturi, nedostatak radne snage u nekim oblastima, itd.), ali i na negativne strane smanjenja prosečne veličine porodice, koja je naročito bila uočljiva u gradskim naseljima. Posledice tih pojava danas su nam dobro poznate.

Rezultati popisa iz 1910. godine dobijaju pravu težinu ukoliko se sagledaju u svetlu rezultata prethodna četiri popisa stanovništva Ugarske, jer se na taj način može formirati na prilično sigurnim, kvantitativnim podacima zasnovana slika razvoja ugarskog društva u doba dualizma. Takve analize sigurno bi bile od koristi ne samo istoričarima već i sociolozima, ekonomistima, demografima i privrednim istoričarima.

Györe Zoltán

Pfeiffer Attila

BASIC DEMOGRAPHIC CHARACTERISTICS OF HUNGARY ACCORDING TO THE POPULATION CENSUS FROM 1910

\section{Summary}

The subject of this research was the general census of the population of Hungary from 1910, with the aim of showing the basic demographic characteristics of its population based on the results of the census. The census was carried out simultaneously throughout the AustroHungarian Empire. The authors paid special attention to the territories of today's Vojvodina. The general population census of Hungary from 1910 is particularly interesting for researchers for several reasons. It was more modern, more comprehensive and more detailed than all the previous Hungarian population censuses. It recorded the state of the population and society in the time closest to the disintegration of the Hungarian state, and it fixed an image of Hungary as of a state with reminiscences of the past, but also with the processes typical of modern capitalist and civic development. The inventory is especially valuable to the researchers, since it included the population of different ethnic and religious affiliations, in areas with many different geographical features, with different economic, social, and cultural preferences, but under the same state-legal framework and for a thousand-year-long common destiny. So, these circumstances could awaken the curiosity of numerous researchers of different profiles, especially from the aspect of the functioning of complex societies.

The results of the census showed the continuity of demographic and social tendencies observed in previous decades. The process of urbanization, intensive internal migration, and a massive migration to the USA, as well as changes in the social structure, were clearly 
visible. In general, the census showed Hungary in development: all the more significant demographic indicators (population increase, population density, improved housing quality, increasing proportion of Hungarians and those who spoke the Hungarian language; stability of families, a noticeable increase in population in urban settlements, a strong attractive force of Budapest, the proliferation of industrial labour, increasing proportion of literates, increasing differences in the structure of the population of cities and rural areas, etc.) testified about the upward path and the development of the Hungarian society. Of course, there were certain signs that provoked serious contemplations and considerations of necessary state measures to take: the consequences of economic emigration have left more and more traces on a number of demographic factors (a significant reduction in real population growth, a gender imbalance, discrete changes in ethnic and religious structure, lack of labour in some areas, etc.); on the basis of the census, contemporaries also pointed to the negative consequences of a decrease in the average family size, which primarily occurred in urban settlements. The consequences of these phenomena are especially well known to us today.

Continuity or cessation of the phenomena noted in this census after the dismemberment of the Kingdom of Hungary can be, with considerable difficulty, investigated through the history of the successor countries to Hungary.

The information that the census of 1910 tells us gets the right weight if we look at the results of the previous four censuses $(1870,1880,1890$, and 1900). In this way, a solid picture of the development of the Hungarian society in the age of dualism can be formed on quite reliable, quantitative data. Such analyses would surely benefit not only historians, but also sociologists, economists, demographers, and economy historians.

Key words: population, census, 1910, Vojvodina, Austria-Hungary, historical demography, migrations, statistics, ethnic and confessional structure.

\section{KORIŠĆENI IZVORI I LITERATURA}

Népszámlálások története. U: A népszámlálásokról. Központi Statisztikai Hivatal. Preuzeto 18.06.2017. sa sajta

http://www.ksh.hu/nepszamlalas/nepszamlalasok_tortenete.

Népszámlálási Digitális Adattár. Központi Statisztikai Hivatal Könyvtára preuzeto 6. 6. 2017. sa sajta: https://library.hungaricana.hu/hu/ collection/kozponti_statisztikai_hivatal_nepszamlalasi_digitalis_adattar/

A Magyar Szent Korona országainak 1910. évi népszámlálása. Első rész. A népesség föbb adatai községek és népesebb puszták, telepek szerint. Magyar Stairsztikai Közlemények, Új sorozat, 42. Budapest: Magyar Királyi Központi Statisztikai Hivatal, Atheneum, 1912. U citatima: Msk, 1912.

A Magyar Szent Korona országainak 1910. évi népszámlálása. Ötödik rész. Részletes demográfia. Magyar Statisztikai Közlemények Új Sorozat, 61. 
Budapest: Magyar Királyi Központi Statisztikai Hivatal, Atheneum, 1916. U citatima: Msk 1916.

Die Ergebnisse der Volkszählung vom 31. Dezember 1910 in den Reichsraten vertretenen, 1. Heft, Die summarische Ergebnisse der Volkszählung mit 6 Kartogrammen. Wien: Bureau der K.K.Statistischen, 1912. U citatima: Kks 1912.

Die Ergebnisse der Volkszählung in Bosnien und Herzegovina vom 10. Oktober 1910. Sarajevo: Statistischen Department der Landesregierung. 1912. U citatima: Sdl 1912.

Buday, L. (Ed.) (1911). Az 1910-es népszámlálás. A Magyar Királyi Központi Statisztikai Hivatal munkássága 1871-1911. Magyar Statisztikai Közlemények Új Sorozat, 36. Budapest: Magyar Királyi Központi Statisztikai Hivatal, Atheneum. 463-503.

Bánszki, H. (2011). Népösszeírások, népszámlálások és statisztikák. Magyar Nemzeti Levéltár SzSzB megyei Levéltára. Preuzeto 29. 06. 2017. sa sajta: http://www.olvasssokat.hu/leveltar/?q=content/n\%C3\%A9p\%C3\%B6ssze\%C3\%ADr\%C3\% A1sok-n\%C3\%A9psz\%C3\%A1ml\%C3\%A11\%C3\%A1sok-\%C3\%A9sstatisztik\%C3\%A1k.

Faragó, T. (2008). A magyarországi történeti demográfiai kutatás vázlatos története a kezdetektől 1945-ig. Történeti Demográfiai Évkönyv, 6, 5-40.

Györe, Z. (1992). Kivándorlás Bács-Bodrog, Torontál és Szerém megyéből 19001910 között. Létünk, 1992, 843-853.

Katus László (2015). Lex Apponyi. Rubicon, 2, 35-36.

Lakatos, M. (2003). A magyar népszámlálások kommunikációja. Statisztikai Szemle, 2, 171-190.

Pomogyi L. (ed.) (2003), Az 1910. évi népszámlálásról. Ezer év törvényei. Preuzeto 18.06.2017. sa sajta, https://1000ev.hu/index.php?a=3\&param=7087.

Tóth P.P. Magyarország népessége 1850-től napjainkig. Korunk, 2002, 2, 23-47.

Rédei, M. (2006). Demográfiai ismeretek, Budapest: ELTE Eötvös.

Macura, M. (ured.) (1953). Stanovništvo Narodne Republike Srbije 1834-1953.

Serija B sveska 1. Beograd: Zavod za statistiku i evidenciju N.R. Srbije.

Hanák P. (1983). Magyarország társadalma a századforduló idején. U: Pach

Zsigmond Pál (ed.) Magyarország története 1890-1918. Budapest:

Akadémiai Kiadó, 412-506. 